\title{
Basophils have emerged as a key player in immunity
}

Short title: Emerging roles of basophils

Hajime Karasuyama ${ }^{1,2}$ and Yoshinori Yamanishi ${ }^{1}$

${ }^{1}$ Department of Immune Regulation, ${ }^{2}$ JST, CREST, Tokyo Medical and Dental University Graduate School of Medical and Dental Sciences, Tokyo 113-8519, Japan

Corresponding author: Karasuyama, Hajime (karasuyama.mbch@tmd.ac.jp)

1-5-45 Yushima, Bunkyo-ku, Tokyo 113-8519, Japan

Phone: $+81-3-5803-5162$

(C) 2014. This manuscript version is made available under the Elsevier user license http://www.elsevier.com/open-access/userlicense/1.0/ 


\begin{abstract}
Basophils had long been neglected in immunological studies, because of their paucity and phenotypic similarity with tissue-resident mast cells. However, recent development of analytical tools has cast new light on this neglected minority, and revealed previously-unappreciated roles of basophils, distinct from those of mast cells, in various immune responses. Primary function of basophils appears to be the protection against infections with parasites, including ticks and helminths. This is why basophils are evolutionally conserved well in many animal species, albeit a small number. Nevertheless, basophils sometimes exert host-deleterious functions in immunological disorders such as allergy. Here we summarize recent advance in our understanding of basophil ontogeny and their in vivo roles under physiological and pathological conditions.
\end{abstract}

\title{
Introduction
}

Basophils are the rarest granulocytes (less than $1 \%$ of peripheral blood leukocytes), and named after basophilic granules in the cytoplasm, as documented first by Paul Ehrlich more than 130 years ago. Since then, the study of basophils had long been hindered by their rarity and short life span, the absence of long-lived cell lines, and the paucity of tools for their detection and functional analysis. Based on their rarity and phenotypic similarity with mast cells, including the presence of basophilic granules in the cytoplasm and the surface expression of high-affinity of IgE receptor, basophils had often erroneously been considered as minor and redundant relatives or blood-circulating precursors of tissue-resident mast cells. This view was held for many years, until the early 1990s when the long-neglected minority gained new respect by the discovery that basophils are an important cellular source of a Th2 cytokine IL-4, suggesting a potential role of basophils in Th2-type immune responses such as allergy and anti-parasitic protective immunity [1]. Indeed, recent development of novel 
analytical tools, in particular, genetically engineered mice in which only basophils are inducibly or constitutively deficient [2-5], has enabled the functional characterization of basophils in vivo, and revealed that basophils play pivotal and non-redundant roles in a variety of immune responses, as outlined in this review.

\section{Ontogeny of basophils}

The life span of circulating basophils is very short ( 2.5 days in mice), and therefore they are continuously replenished from progenitors in the bone marrow. The origin and developmental pathway of basophils in the bone marrow long remained enigmatic until recently. Accumulating evidence indicates a close lineage relationship of basophils with mast cells in mice [6,7]. The ordered expression of two transcription factors, GATA-2 and C/EBP $\alpha$, regulates the lineage commitment of basophils [8]. C/EBP $\alpha$ and MITF silence each other's transcription in a directly antagonistic fashion, and specify basophil and mast cell fate, respectively [9*]. Ikaros limits basophil development by suppressing C/EBP $\alpha$ expression [10]. Interestingly, mice deficient for P1-Runx1 show severe basophilopenia with no apparent anomaly of mast cells, indicating a crucial role of P1-Runx1 in the differentiation of basophils but not mast cells [11]. Besides GATA-2, GATA-1 also plays an important role in the generation and function of basophils [12*]. Accordingly, $\Delta$ dblGATA mice carrying the mutated Gatal promoter show numerical and functional aberrancy in basophils in addition to the known deficiency of eosinophils. It is notable that a transforming MYB-GATAl fusion gene was identified in acute basophilic leukemia of humans [13].

In humans, in contrast to mice, basophils seem to have a closer lineage relationship with eosinophils, as demonstrated, for example, by the presence of immature basophils with a basophil-eosinophil hybrid phenotype [14]. Recent establishment of mice reconstituted with human myeloid cells [15] may help study the differentiation pathway of human basophils. 
Intriguingly, basophil hematopoiesis appears to be influenced by serum $\operatorname{IgE}$ levels [16*], and elevated IgE concentration correlates with increased numbers of circulating basophils in both mice and humans $\left[16^{*}, 17\right]$. It is suggested that $\operatorname{IgE}$ binding to its high

affinity receptor on basophil precursors in the bone marrow upregulates their IL-3R $\alpha$ (CD123) expression, leading to increased responsiveness to IL-3 and hence their expansion $\left[16^{*}\right]$.

\section{Do basophils function as antigen-presenting cells (APCs)?}

This has remained a matter of debate since 2009 when three groups independently reported the exciting discovery that basophils, rather than dendritic cells, are the critical APCs for driving Th2 cell differentiation in mice [18-20]. Basophils express surface molecules necessary for APC function, including MHC class II and co-stimulatory molecules such as CD80, CD86 and CD40, and can process and present antigens and provide IL-4 to naïve CD4 T cells, leading to their differentiation into the Th2 cell type. However, the full extent of the role of basophils in antigen presentation and Th2 differentiation remains uncertain, and conflicting conclusions were drawn, depending on different experimental settings [3,4,21-29]. Of note, Otsuka et al. recently reported that basophils are responsible for Th2 skewing to haptens and peptide antigens, but not protein antigens in vivo, while basophil can promote Th2 skewing for protein antigens in the presence of dendritic cells [30*]. So far no evidence for APC activity of human basophils has been provided [31-35].

There are several points to be considered in evaluating the APC activity of basophils, including the purity of isolated basophils, the cytokine milieu surrounding basophils, off-target effects of basophil-depleting reagents, and possible difference between peripheral blood basophils and those accumulating in lymph nodes and affected tissues. Establishment of more sophisticated tools such as basophil-restricted MHC class II-deficient 
mice would help to solve this controversial issue.

\section{Versatile roles of basophil-derived IL-4}

Basophils from both humans and mice rapidly secrete large quantities of IL-4 in response to various stimuli. Recent studies have identified versatile roles of basophil-derived IL-4 in immune responses, in addition to its role in Th2 cell differentiation as described above (Figure 1). Basophil-derived IL-4 stimulates B cells to enhance antibody production in protective immunity [36,37] and in autoimmunity [38]. In papain-induced eosinophilic lung inflammation, activated basophils secrete IL-4 that acts on natural helper cells, a member of group 2 innate lymphoid cells, to enhance their production of chemokine CCL11 (eotaxin) and cytokines IL-5, IL-9 and IL-13, leading to eosinophilic inflammation [39**]. Basophil-derived IL-4 can act on fibroblasts in vitro to promote CCL11 expression, and basophils appear to contribute to eosinophil recruitment in a mouse model of irritant contact dermatitis [40].

Intriguingly, basophil-derived IL-4 also plays a regulatory role in allergic inflammation. In basophil-elicited, IgE-mediated chronic allergic inflammation [41], skin-infiltrating basophils secrete IL-4, which in turn act on inflammatory monocytes recruited to the skin, leading to the generation of M2-type macrophages that dampen allergic inflammation [42**]. Basophil-derived IL-4 has also been shown to act on macrophages to promote increased expression of the inhibitory Fc receptor Fc $\gamma$ RIIB on the surface, leading to the suppression of inflammation in an arthritis model of mice when treated with high dose intravenous immunoglobulin [43], even though a later study contradicted the basophil involvement in the suppression [44]. Basophils appear to limit disease activity in a mouse model of colitis through production of IL-4 that downregulates Th1 cytokine expression in T cells [45]. 


\section{Distinct roles of TSLP-elicited basophils}

Recent studies suggest that basophils may be a heterogeneous population of cells, and their development can be influenced by distinct cytokines, including IL-3 and thymic stromal lymphopoietin (TSLP), although basophils can be generated at a steady-state level even in the absence of both cytokines [46]. TSLP-elicited basophils exhibit a distinct pattern of gene expression, compared with classical IL-3-elicited basophils. The former displays higher expression of receptors for IL-18 and IL-33 to respond more robustly to these cytokines and produce more IL-4 and IL-6 than the latter while the latter shows higher responsiveness to IgE-antigen stimulation [46,47]. The unique association of the IL-3 receptor with FcR $\gamma$, a component of the IgE receptor FceRI, in basophils may be related with the $\operatorname{IgE}$ responsiveness of IL-3-elicited basophils [48]. Collectively, TSLP- and IL-3-elicited basophils appear to have tendency to contribute to IgE-independent (innate) and IgE-dependent (acquired) immune responses, respectively (Figure 2). Indeed, a recent study has demonstrated in mice that TSLP-elicited basophils contribute to the pathogenesis of eosinophilic esophagitis, a food allergy-associated inflammatory disease, in an IgE-independent manner [49**]. Importantly, elevated TSLP expression and exaggerated basophil response were observed in esophageal biopsy samples from eosinophilic esophagitis patients, and a gain-of-function of TSLP polymorphism was associated with increased basophil responses in patients. TSLP-elicited basophils are also attributed to the pathogenesis of atopic dermatitis [46,50] and cutaneously-sensitized food allergy [51,52], as well as the promotion of Th2 cytokine responses to helminth infection [53]. Thus, the TSLP-basophil pathway could be a promising target for controlling Th2-type immunity and inflammation.

\section{Basophils in allergy}


Anaphylaxis is an acute-onset, life-threatening allergic reaction. Besides the classic mode of anaphylaxis in that IgE, mast cells and histamine play crucial roles, IgG- and platelet-activating factor (PAF)-mediated anaphylaxis has been demonstrated in mouse models. Mast cells are dispensable for the latter type of anaphylaxis, and three distinct cell lineages (basophils, macrophages, and neutrophils) have been reported as PAF-producing effector cells under different experimental conditions [54-56]. A series of recent studies tried to elucidate which cell type is indeed crucial for IgG- and PAF-mediated systemic anaphylaxis, and concluded that either basophils [57], macrophages [58] or all three cell types [59] are the major players, confirming that their relative contribution depends on experimental settings. Interestingly, intravenous injection of anti-asialo GM1 antibody activates basophils but not mast cells to produce PAF, and results in anaphylaxis-like shock in mice [60], illustrating the ability of basophils to elicit PAF-mediated anaphylaxis. Both basophils and mast cells contribute to peanut-induced active systemic anaphylaxis in mice [61], most likely in IgG- and IgE-dependent manner, respectively. While previous studies reported the dispensable role for basophils in IgE-mediated anaphylaxis [5,54], a recent study using $\operatorname{IgE}$ knock-in (in place of IgG1) mice suggested some contribution of basophils to IgE-mediated anaphylaxis in an active sensitization model [62], even though the involvement of IgG subclasses other than IgG1 [59] cannot be formally excluded in this model of anaphylaxis.

Chronic idiopathic urticaria is defined as long-lasting itchy hives with no apparent triggers, and its pathogenesis remains unclear. A recent clinical trial has cast new light on our understanding of underlying mechanism. Anti-IgE antibody (Omalizumab) significantly reduced clinical symptoms and signs of patients who were resistant to $\mathrm{H} 1$-antihistamine therapy [63*]. The Omalizumab administration shows a therapeutic effect within a week. Of note, down-regulation of FceRI on blood basophils is observed within 2 weeks after Omalizumab administration while that on mast cells typically occurs after 8 weeks. Taken 
together with the observation that basophils infiltrated affected skin [64,65], $\operatorname{IgE}$ and basophils may contribute to the pathogenesis of chronic idiopathic urticaria.

\section{Basophils in protective immunity against parasitic infections}

Basophils are evolutionarily conserved in many animal species, albeit a minor population among leukocytes, suggesting a beneficial rather than deleterious role of basophils. Indeed, basophils have been demonstrated to play a crucial role in acquired protective immunity to infestation with blood-sucking ticks [2]. IgE-armed basophils are recruited to and accumulated in tick feeding sites of the skin during the second but not first infestation, and selective basophil ablation leads to the loss of resistance against tick feeding observed in the second infestation. By contrast, the role of basophils in acquired protective immunity against helminthic infections remained controversial [3,4]. A recent study with a mouse model of hookworm infections has revealed a novel mode of anti-helminth immunity in that skin-infiltrating basophils provide acquired protection against intestinal helminths by means of restraining skin-invading larvae from migration toward the lung and intestine, rather than expelling adult worms from the intestine [66**]. IgE-armed basophils recruited to the skin are activated in response to helminth antigens, and produce IL-4 that in turn promotes the generation of M2-type macrophages, leading to the larval trapping in the skin through ariginase-1 production. Thus, basophil- and IgE-mediated acquired immunity in the skin appears to be important for the resistance to reinfection of both ecto- and endo-parasites. Moreover, basophils have been shown to help establish protective immunity induced by irradiated larval vaccination for filariasis [67], and to contribute to granuloma formation induced by Schistosoma mansoni eggs [68].

\section{Concluding remarks}


Recent technological advances in basophil research have illustrated that basophils have pivotal roles in vivo, distinct from those of mast cells, in spite of their small number. Accumulating evidence suggests that the primary function of basophils is protection against parasitic infections while they often contribute to the development and exacerbation of allergic disorders under parasite-free conditions. Although functional study on human basophils is limited compared to murine one, recent analyses of human samples have extended the notion that basophils are recruited to affected tissues and may contribute to allergic responses or protective immunity against parasitic infections in humans $[49,65,69,70]$. Therefore, further elucidation of the molecular mechanisms underlying basophil-mediated allergic inflammation and protective immunity will help the establishment of a new strategy for allergy treatment and the development of efficient vaccination against parasites, respectively.

\section{Acknowledgements}

This work is supported by research grants from Japan Science and Technology Agency (Core Research for Evolutional Science and Technology), and the Japanese Ministry of Education, Culture, Sports, Science and Technology. The authors apologize for not citing all relevant publications due to space limitations. 


\section{References}

$*$ of special interest, $* *$ of outstanding interest

1. Karasuyama H, Mukai K, Obata K, Tsujimura Y, Wada T: Nonredundant roles of basophils in immunity. Annu Rev Immunol 2011, 29:45-69.

2. Wada T, Ishiwata K, Koseki H, Ishikura T, Ugajin T, Ohnuma N, Obata K, Ishikawa R, Yoshikawa S, Mukai K, et al.: Selective ablation of basophils in mice reveals their nonredundant role in acquired immunity against ticks. J Clin Invest 2010, 120:2867-2875.

3. Ohnmacht C, Schwartz C, Panzer M, Schiedewitz I, Naumann R, Voehringer D: Basophils orchestrate chronic allergic dermatitis and protective immunity against helminths. Immunity 2010, 33:364-374.

4. Sullivan BM, Liang HE, Bando JK, Wu D, Cheng LE, McKerrow JK, Allen CD, Locksley RM: Genetic analysis of basophil function in vivo. Nat Immunol 2011, 12:527-535.

5. Sawaguchi M, Tanaka S, Nakatani Y, Harada Y, Mukai K, Matsunaga Y, Ishiwata K, Oboki K, Kambayashi T, Watanabe N, et al.: Role of mast cells and basophils in IgE responses and in allergic airway hyperresponsiveness. $J$ Immunol 2012, 188:1809-1818.

6. Arinobu Y, Iwasaki H, Gurish MF, Mizuno S, Shigematsu H, Ozawa H, Tenen DG, Austen KF, Akashi K: Developmental checkpoints of the basophil/mast cell lineages in adult murine hematopoiesis. Proc Natl Acad Sci U S A 2005, 102:18105-18110.

7. Metcalf D, Ng AP, Baldwin TM, Di Rago L, Mifsud S: Concordant mast cell and basophil production by individual hematopoietic blast colony-forming cells. Proc Natl Acad Sci U S A 2013, 110:9031-9035.

8. Iwasaki H, Mizuno S, Arinobu Y, Ozawa H, Mori Y, Shigematsu H, Takatsu K, Tenen 
DG, Akashi K: The order of expression of transcription factors directs hierarchical specification of hematopoietic lineages. Genes Dev 2006, 20:3010-3021.

9. *Qi X, Hong J, Chaves L, Zhuang Y, Chen Y, Wang D, Chabon J, Graham B, Ohmori K, Li Y, et al.: Antagonistic regulation by the transcription factors C/EBPalpha and MITF specifies basophil and mast cell fates. Immunity 2013, 39:97-110.

This study demonstrates that the transcription factors $\mathrm{C} / \mathrm{EBP} \alpha$ and MITF silence each other in a subset of granulocyte-macrophage progenitors, and specify the lineage commitment of basophils and mast cells, respectively.

10. Rao KN, Smuda C, Gregory GD, Min B, Brown MA: Ikaros limits basophil development by suppressing C/EBP-alpha expression. Blood 2013, 122:2572-2581.

11. Mukai K, BenBarak MJ, Tachibana M, Nishida K, Karasuyama H, Taniuchi I, Galli SJ: Critical role of P1-Runx1 in mouse basophil development. Blood 2012, 120:76-85.

12. *Nei Y, Obata-Ninomiya K, Tsutsui H, Ishiwata K, Miyasaka M, Matsumoto K, Nakae S, Kanuka H, Inase N, Karasuyama H: GATA-1 regulates the generation and function of basophils. Proc Natl Acad Sci U S A 2013, 110:18620-18625.

The study shows that GATA-1 plays a key role in the development and function of basophils, and that $\triangle$ dblGATA mice have numerical and functional aberrancy in basophils, in addition to the known deficiency of eosinophils.

13. Quelen C, Lippert E, Struski S, Demur C, Soler G, Prade N, Delabesse E, Broccardo C, Dastugue N, Mahon FX, et al.: Identification of a transforming MYB-GATA1 fusion gene in acute basophilic leukemia: a new entity in male infants. Blood 2011, 117:5719-5722.

14. Grundstrom J, Reimer JM, Magnusson SE, Nilsson G, Wernersson S, Hellman L: Human cord blood derived immature basophils show dual characteristics, expressing both basophil and eosinophil associated proteins. PLoS One 2012, 
7:e48308.

15. Ito R, Takahashi T, Katano I, Kawai K, Kamisako T, Ogura T, Ida-Tanaka M, Suemizu $\mathrm{H}$, Nunomura S, Ra C, et al.: Establishment of a human allergy model using human IL-3/GM-CSF-transgenic NOG mice. J Immunol 2013, 191:2890-2899.

16. *Hill DA, Siracusa MC, Abt MC, Kim BS, Kobuley D, Kubo M, Kambayashi T, Larosa DF, Renner ED, Orange JS, et al.: Commensal bacteria-derived signals regulate basophil hematopoiesis and allergic inflammation. Nat Med 2012, 18:538-546.

This is the first study to show commensal bacteria-derived signals limit IgE production, hence basophil hematopoiesis and basophil-associated allergic inflammation.

17. Cahenzli J, Koller Y, Wyss M, Geuking MB, McCoy KD: Intestinal microbial diversity during early-life colonization shapes long-term IgE levels. Cell Host Microbe 2013, 14:559-570.

18. Sokol CL, Chu NQ, Yu S, Nish SA, Laufer TM, Medzhitov R: Basophils function as antigen-presenting cells for an allergen-induced $\mathbf{T}$ helper type 2 response. Nat Immunol 2009, 10:713-720.

19. Yoshimoto T, Yasuda K, Tanaka H, Nakahira M, Imai Y, Fujimori Y, Nakanishi K: Basophils contribute to $\mathrm{T}(\mathrm{H}) 2$-IgE responses in vivo via IL-4 production and presentation of peptide-MHC class II complexes to CD4+ T cells. Nat Immunol 2009, 10:706-712.

20. Perrigoue JG, Saenz SA, Siracusa MC, Allenspach EJ, Taylor BC, Giacomin PR, Nair MG, Du Y, Zaph C, van Rooijen N, et al.: MHC class II-dependent basophil-CD4+ T cell interactions promote $\mathbf{T}(\mathbf{H}) 2$ cytokine-dependent immunity. Nat Immunol 2009, 10:697-705.

21. Hammad H, Plantinga M, Deswarte K, Pouliot P, Willart MA, Kool M, Muskens F, Lambrecht BN: Inflammatory dendritic cells--not basophils--are necessary and 
sufficient for induction of Th2 immunity to inhaled house dust mite allergen. $J \operatorname{Exp}$ Med 2010, 207:2097-2111.

22. Kim S, Prout M, Ramshaw H, Lopez AF, LeGros G, Min B: Cutting edge: basophils are transiently recruited into the draining lymph nodes during helminth infection via IL-3, but infection-induced Th2 immunity can develop without basophil lymph node recruitment or IL-3. J Immunol 2010, 184:1143-1147.

23. Phythian-Adams AT, Cook PC, Lundie RJ, Jones LH, Smith KA, Barr TA, Hochweller K, Anderton SM, Hammerling GJ, Maizels RM, et al.: CD11c depletion severely disrupts Th2 induction and development in vivo. J Exp Med 2010, 207:2089-2096.

24. Tawara I, Nieves E, Liu C, Evers R, Toubai T, Sun Y, Alrubaie M, Reddy P: Host basophils are dispensable for induction of donor $\mathbf{T}$ helper 2 cell differentiation and severity of experimental graft-versus-host disease. Biol Blood Marrow Transplant 2011, 17:1747-1753.

25. Wakahara K, Van VQ, Baba N, Begin P, Rubio M, Delespesse G, Sarfati M: Basophils are recruited to inflamed lungs and exacerbate memory Th2 responses in mice and humans. Allergy 2013, 68:180-189.

26. Leyva-Castillo JM, Hener P, Michea P, Karasuyama H, Chan S, Soumelis V, Li M: Skin thymic stromal lymphopoietin initiates Th2 responses through an orchestrated immune cascade. Nat Commun 2013, 4:2847.

27. Suurmond J, Stoop JN, Rivellese F, Bakker AM, Huizinga TW, Toes RE: Activation of human basophils by combined toll-like receptor- and FcepsilonRI-triggering can promote Th2 skewing of naive T helper cells. Eur J Immunol 2014, 44:386-396.

28. Zhong W, Su W, Zhang Y, Liu Q, Wu J, Di C, Zhang Z, Xia Z: Basophils as a primary inducer of the $T$ helper type 2 immunity in ovalbumin-induced allergic airway inflammation. Immunology 2014, 142:202-215. 
29. Tang H, Cao W, Kasturi SP, Ravindran R, Nakaya HI, Kundu K, Murthy N, Kepler TB, Malissen B, Pulendran B: The T helper type 2 response to cysteine proteases requires dendritic cell-basophil cooperation via ROS-mediated signaling. Nat Immunol 2010, 11:608-617.

30. *Otsuka A, Nakajima S, Kubo M, Egawa G, Honda T, Kitoh A, Nomura T, Hanakawa S, Sagita Moniaga C, Kim B, et al.: Basophils are required for the induction of Th2 immunity to haptens and peptide antigens. Nat Commun 2013, 4:1739.

This study shows that basophils cannot take up or process protein antigens while they do induce Th2 skewing for haptens and peptide antigens. Basophils require dendritic cells for induction of Th2 differentiation for protein antigens.

31. Kitzmuller C, Nagl B, Deifl S, Walterskirchen C, Jahn-Schmid B, Zlabinger GJ, Bohle B: Human blood basophils do not act as antigen-presenting cells for the major birch pollen allergen Bet v 1. Allergy 2012, 67:593-600.

32. Dijkstra D, Hennig C, Witte T, Hansen G: Basophils from humans with systemic lupus erythematosus do not express MHC-II. Nat Med 2012, 18:488-489; author reply 489-490.

33. Eckl-Dorna J, Ellinger A, Blatt K, Ghanim V, Steiner I, Pavelka M, Valent P, Valenta R, Niederberger V: Basophils are not the key antigen-presenting cells in allergic patients. Allergy 2012, 67:601-608.

34. Sharma M, Hegde P, Aimanianda V, Beau R, Maddur MS, Senechal H, Poncet P, Latge JP, Kaveri SV, Bayry J: Circulating human basophils lack the features of professional antigen presenting cells. Sci Rep 2013, 3:1188.

35. Voskamp AL, Prickett SR, Mackay F, Rolland JM, O'Hehir RE: MHC class II expression in human basophils: induction and lack of functional significance. PLoS One 2013, 8:e81777. 
36. Denzel A, Maus UA, Rodriguez Gomez M, Moll C, Niedermeier M, Winter C, Maus R, Hollingshead S, Briles DE, Kunz-Schughart LA, et al.: Basophils enhance immunological memory responses. Nat Immunol 2008, 9:733-742.

37. Chen K, Xu W, Wilson M, He B, Miller NW, Bengten E, Edholm ES, Santini PA, Rath P, Chiu A, et al.: Immunoglobulin D enhances immune surveillance by activating antimicrobial, proinflammatory and B cell-stimulating programs in basophils. Nat Immunol 2009, 10:889-898.

38. Charles N, Hardwick D, Daugas E, Illei GG, Rivera J: Basophils and the T helper 2 environment can promote the development of lupus nephritis. Nat Med 2010, 16:701-707.

39. **Motomura Y, Morita H, Moro K, Nakae S, Artis D, Endo TA, Kuroki Y, Ohara O, Koyasu S, Kubo M: Basophil-Derived Interleukin-4 Controls the Function of Natural Helper Cells, a Member of ILC2s, in Lung Inflammation. Immunity 2014, 40:758-771.

This study demonstrates that basophils are essential for protease allergen-induced airway responses, in that basophil-derived IL-4 acts on natural helper cells to enhance the expression of chemokine CCL11 and cytokines IL-5, IL-9, and IL-13, leading to eosinophilic lung inflammation.

40. Nakashima C, Otsuka A, Kitoh A, Honda T, Egawa G, Nakajima S, Nakamizo S, Arita M, Kubo M, Miyachi Y, et al.: Basophils regulate the recruitment of eosinophils in a murine model of irritant contact dermatitis. J Allergy Clin Immunol 2014.

41. Mukai K, Matsuoka K, Taya C, Suzuki H, Yokozeki H, Nishioka K, Hirokawa K, Etori M, Yamashita M, Kubota T, et al.: Basophils play a critical role in the development of IgE-mediated chronic allergic inflammation independently of $\mathbf{T}$ cells and mast cells. Immunity 2005, 23:191-202. 
42. **Egawa M, Mukai K, Yoshikawa S, Iki M, Mukaida N, Kawano Y, Minegishi Y, Karasuyama $\mathrm{H}$ : Inflammatory monocytes recruited to allergic skin acquire an anti-inflammatory M2 phenotype via basophil-derived interleukin-4. Immunity 2013, 38:570-580.

This study shows that in basophil-elicited, IgE-mediated chronic allergic inflammation, basophil-derived IL-4 acts on inflammatory monocytes recruited to the skin lesion, leading their differentiation into M2-type macrophages that in turn dampen the allergic inflammation.

43. Anthony RM, Kobayashi T, Wermeling F, Ravetch JV: Intravenous gammaglobulin suppresses inflammation through a novel T(H)2 pathway. Nature 2011, 475:110-113.

44. Campbell IK, Miescher S, Branch DR, Mott PJ, Lazarus AH, Han D, Maraskovsky E, Zuercher AW, Neschadim A, Leontyev D, et al.: Therapeutic Effect of IVIG on Inflammatory Arthritis in Mice Is Dependent on the Fc Portion and Independent of Sialylation or Basophils. J Immunol 2014, 192:5031-5038.

45. Gomez MR, Talke Y, Hofmann C, Ketelsen I, Hermann F, Reich B, Goebel N, Schmidbauer K, Dunger N, Bruhl H, et al.: Basophils control T-cell responses and limit disease activity in experimental murine colitis. Mucosal Immunol 2014, 7:188-199.

46. Siracusa MC, Saenz SA, Hill DA, Kim BS, Headley MB, Doering TA, Wherry EJ, Jessup HK, Siegel LA, Kambayashi T, et al.: TSLP promotes interleukin-3-independent basophil haematopoiesis and type 2 inflammation. Nature 2011, 477:229-233.

47. Siracusa MC, Kim BS, Spergel JM, Artis D: Basophils and allergic inflammation. $J$ Allergy Clin Immunol 2013, 132:789-801; quiz 788.

48. Hida S, Yamasaki S, Sakamoto Y, Takamoto M, Obata K, Takai T, Karasuyama H, 
Sugane K, Saito T, Taki S: Fc receptor gamma-chain, a constitutive component of the IL-3 receptor, is required for IL-3-induced IL-4 production in basophils. Nat Immunol 2009, 10:214-222.

49. **Noti M, Wojno ED, Kim BS, Siracusa MC, Giacomin PR, Nair MG, Benitez AJ, Ruymann KR, Muir AB, Hill DA, et al.: Thymic stromal lymphopoietin-elicited basophil responses promote essinophilic esophagitis. Nat Med 2013, 19:1005-1013.

The study shows that TSLP-elicited basophils contribute to the pathogenesis of an eosinophilic esophagitis-like disease in an IgE-independent manner.

50. Moniaga CS, Jeong SK, Egawa G, Nakajima S, Hara-Chikuma M, Jeon JE, Lee SH, Hibino T, Miyachi Y, Kabashima K: Protease activity enhances production of thymic stromal lymphopoietin and basophil accumulation in flaky tail mice. Am J Pathol 2013, 182:841-851.

51. Noti M, Kim BS, Siracusa MC, Rak GD, Kubo M, Moghaddam AE, Sattentau QA, Comeau MR, Spergel JM, Artis D: Exposure to food allergens through inflamed skin promotes intestinal food allergy through the thymic stromal lymphopoietin-basophil axis. J Allergy Clin Immunol 2014, 133:1390-1399, 1399 e1391-1396.

52. Muto T, Fukuoka A, Kabashima K, Ziegler SF, Nakanishi K, Matsushita K, Yoshimoto T: The role of basophils and pro-allergic cytokines, TSLP and IL-33, in cutaneously-sensitized food allergy. Int Immunol 2014.

53. Giacomin PR, Siracusa MC, Walsh KP, Grencis RK, Kubo M, Comeau MR, Artis D: Thymic stromal lymphopoietin-dependent basophils promote Th2 cytokine responses following intestinal helminth infection. J Immunol 2012, 189:4371-4378.

54. Tsujimura Y, Obata K, Mukai K, Shindou H, Yoshida M, Nishikado H, Kawano Y, Minegishi Y, Shimizu T, Karasuyama $\mathrm{H}$ : Basophils play a pivotal role in 
immunoglobulin-G-mediated but not immunoglobulin-E-mediated systemic anaphylaxis. Immunity 2008, 28:581-589.

55. Strait RT, Morris SC, Yang M, Qu XW, Finkelman FD: Pathways of anaphylaxis in the mouse. J Allergy Clin Immunol 2002, 109:658-668.

56. Jonsson F, Mancardi DA, Kita Y, Karasuyama H, Iannascoli B, Van Rooijen N, Shimizu T, Daeron M, Bruhns P: Mouse and human neutrophils induce anaphylaxis. J Clin Invest 2011, 121:1484-1496.

57. Murphy JT, Burey AP, Beebe AM, Gu D, Presta LG, Merghoub T, Wolchok JD: Anaphylaxis caused by repetitive doses of a GITR agonist monoclonal antibody in mice. Blood 2014, 123:2172-2180.

58. Jiao D, Liu Y, Lu X, Liu B, Pan Q, Liu Y, Liu Y, Zhu P, Fu N: Macrophages are the dominant effector cells responsible for IgG-mediated passive systemic anaphylaxis challenged by natural protein antigen in BALB/c and C57BL/6 mice. Cell Immunol 2014, 289:97-105.

59. Khodoun MV, Kucuk ZY, Strait RT, Krishnamurthy D, Janek K, Clay CD, Morris SC, Finkelman FD: Rapid desensitization of mice with anti-FcgammaRIIb/FcgammaRIII mAb safely prevents IgG-mediated anaphylaxis. J Allergy Clin Immunol 2013, 132:1375-1387.

60. Yang Y, Li D, Katirai F, Zhang B, Xu Y, Xiong P, Gong F, Zheng F: Basophil activation through ASGM1 stimulation triggers PAF release and anaphylaxis-like shock in mice. Eur J Immunol 2014.

61. Reber LL, Marichal T, Mukai K, Kita Y, Tokuoka SM, Roers A, Hartmann K, Karasuyama H, Nadeau KC, Tsai M, et al.: Selective ablation of mast cells or basophils reduces peanut-induced anaphylaxis in mice. J Allergy Clin Immunol 2013, 132:881-888 e881-811. 
62. Lubben W, Turqueti-Neves A, Okhrimenko A, Stoberl C, Schmidt V, Pfeffer K, Dehnert S, Wunsche S, Storsberg S, Paul S, et al.: IgE knock-in mice suggest a role for high levels of IgE in basophil-mediated active systemic anaphylaxis. Eur J Immunol 2013, 43:1231-1242.

63. *Maurer M, Rosen K, Hsieh HJ, Saini S, Grattan C, Gimenez-Arnau A, Agarwal S, Doyle R, Canvin J, Kaplan A, et al.: Omalizumab for the treatment of chronic idiopathic or spontaneous urticaria. N Engl J Med 2013, 368:924-935.

This phase 3 study shows that the anti-IgE (Omalizumab) treatment can diminish clinical symptoms and signs of chronic idiopathic urticaria which is resistant to $\mathrm{H} 1$-antihistamine therapy.

64. Ying S, Kikuchi Y, Meng Q, Kay AB, Kaplan AP: TH1/TH2 cytokines and inflammatory cells in skin biopsy specimens from patients with chronic idiopathic urticaria: comparison with the allergen-induced late-phase cutaneous reaction. $J$ Allergy Clin Immunol 2002, 109:694-700.

65. Ito Y, Satoh T, Takayama K, Miyagishi C, Walls AF, Yokozeki H: Basophil recruitment and activation in inflammatory skin diseases. Allergy 2011, 66:1107-1113.

66. **Obata-Ninomiya $\mathrm{K}$, Ishiwata $\mathrm{K}$, Tsutsui $\mathrm{H}$, Nei $\mathrm{Y}$, Yoshikawa S, Kawano $\mathrm{Y}$, Minegishi $\mathrm{Y}$, Ohta $\mathrm{N}$, Watanabe $\mathrm{N}$, Kanuka $\mathrm{H}$, et al.: The skin is an important bulwark of acquired immunity against intestinal helminths. J Exp Med 2013, 210:2583-2595.

This study shows that basophils recruited to helminth larva-infected skin produce IL-4 that in turn promotes the generation of M2-type macrophages, leading to the larval trapping in the skin through arginase-1 production, thereby limiting the spread of helminth infection to the lung and intestine. 
67. Torrero MN, Morris CP, Mitre BK, Hubner MP, Fox EM, Karasuyama H, Mitre E: Basophils help establish protective immunity induced by irradiated larval vaccination for filariasis. Vaccine 2013, 31:3675-3682.

68. Anyan WK, Seki T, Kumagai T, Obata-Ninomiya K, Furushima-Shimogawara R, Kwansa-Bentum B, Akao N, Bosompem KM, Boakye DA, Wilson MD, et al.: Basophil depletion downregulates Schistosoma mansoni egg-induced granuloma formation. Parasitol Int 2013, 62:508-513.

69. Matsuda A, Ebihara N, Yokoi N, Okayama Y, Watanabe Y, Kawasaki S, Tanioka H, Walls AF, Hamuro J, Kinoshita S, et al.: Basophils in the giant papillae of chronic allergic keratoconjunctivitis. Br J Ophthalmol 2010, 94:513-518.

70. Dijkstra D, Hennig C, Hansen G, Biller H, Krug N, Hohlfeld JM: Identification and quantification of basophils in the airways of asthmatics following segmental allergen challenge. Cytometry A 2014. 


\section{Figure legends}

\section{Figure 1. Versatile roles of basophil-derived IL-4 in immune responses}

Activated basophils secrete large quantities of IL-4 that shows pleiotropic functions in immune responses through action on a variety of cell types, including lymphocytes ( $\mathrm{T}$ and $\mathrm{B}$ cells), innate lymphoid cells (ILC2), myeloid cells (monocytes and macrophages), and non-immune cells (fibroblasts).

\section{Figure 2. Functional heterogeneity between TSLP- and IL-3-elicited basophils}

Basophils appear to display functional heterogeneity, depending on the cytokine milieu during their development in the bone marrow. Epithelial cell-derived TSLP and T cell-derived IL-3 can independently promote the generation and expansion of the basophil cell lineage. TSLP-elicited basophils are less granular and produce higher levels of IL-4 and IL-6 in response to the IL-18 or IL-33 stimulation, compared to IL-3-elicted basophils. IL-3-elicited basophils are more granular and highly responsive to IgE-antigen complexes, compared to TSLP-elicited basophils. Thus, TSLP- and IL-3-elicited basophils trend to contribute to innate and acquired immune responses, respectively. 


\section{Naïve CD4+ ${ }^{+} \mathrm{T}$ cells}

Th2 cell

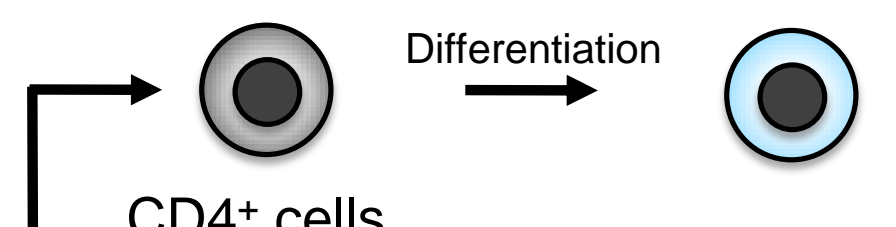

$\underline{\text { References }}$

$18,19,20,29$

\section{5}

$B$ cells

$$
\left\{\begin{array}{l}
\text { IL- } 2 \downarrow \\
\text { IFN- } \gamma \downarrow \\
\text { TNF- } \alpha \downarrow
\end{array}\right.
$$

Immunoglobulin $\uparrow$

$36,37,38$

ILC2 cells

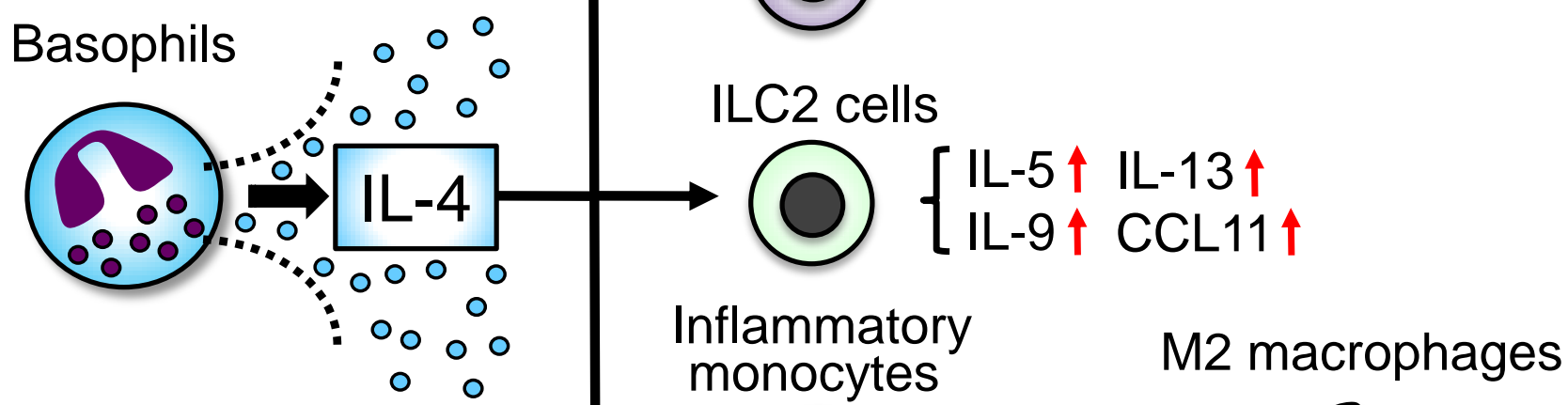

Fibroblasts

Differentiation

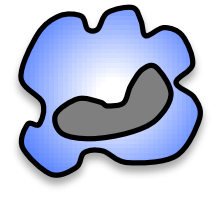

Macrophages

Fc $\gamma$ RIIB $\uparrow$

3 
Figure 2

Innate immune responses

TSLP-elicited basophils

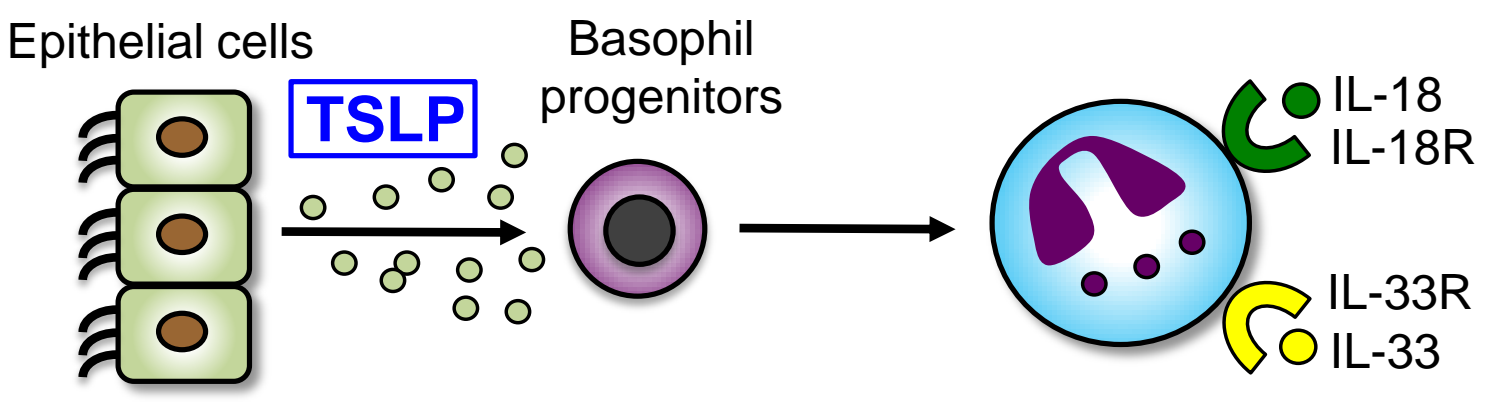

IL-3-elicited basophils
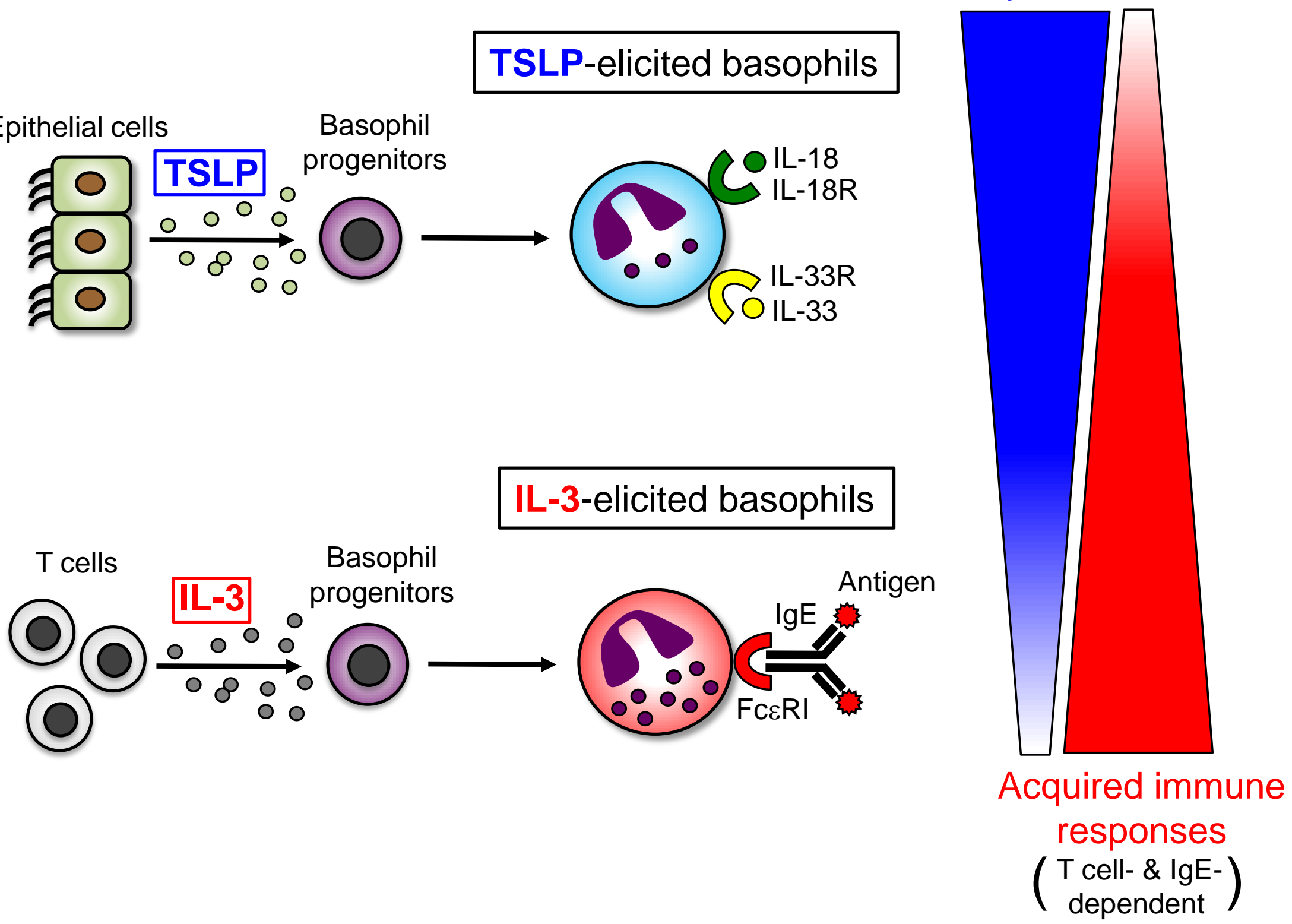